\title{
Cirurgia e Patologia
}

\section{Joffre M. de Rezende ${ }^{1}$}

1. Professor Emérito da Faculdade de Medicina da Universidade Federal de Goiás

A linguagem médica fundamenta-se em uma terminologia baseada na etimologia e na evolução semântica das palavras. Muitas vezes, o significado de um termo modifica-se com o tempo acompanhando a aquisição de novos conhecimentos. É o caso da palavra artéria, assim chamada porque se pensava que conduzia ar. Descoberta a circulação do sangue, verificou-se que conduzia sangue, mas nem por isso seu nome foi mudado.

Quando Andry, em 1741, criou a palavra Ortopedia (do grego orthós, reto + paidós, criança + sufixo -ia) tinha em mente a correção ou prevenção de deformidades congênitas ou adquiridas em crianças. A especialidade estendeu-se aos adultos e ampliou o seu campo de ação, porém o nome se manteve. Tais mudanças semânticas, em que as palavras se desvinculam de suas raízes etimológicas, decorrem da própria evolução da medicina. Muitos outros exemplos poderiam ser dados de termos médicos que adquiriram novas acepções além da primitiva.

Muito diverso, entretanto, é o caso do emprego de termos consagrados na terminologia médica com significado diferente do tradicional, por equívoco, por descaso ou por influência da linguagem coloquial. É incompreensível, por exemplo, o emprego, que se está tornando freqüente em escritos médicos, de "raio-X" por "radiografia”. Muitas dessas aberrações acabam se incorporando ao vocabulário médico em caráter definitivo pelo uso generalizado.

É o que está ocorrendo com os termos "cirurgia” e "patologia”. Cirurgia provém do latim chirurgia, que o tomou do grego kheirourgia, de kheír, mão + érgon, trabalho. Etimologicamente, portanto, cirurgia significa trabalho manual, arte, ofício, no qual se empregam as mãos para a sua execução. Entende-se, assim, o seu uso em medicina para designar os procedimentos terapêuticos que exigem trabalho manual.

De acordo com os melhores léxicos, especializados ou não em termos médicos, define-se cirurgia como o ramo da medicina que se dedica ao tratamento das doenças, lesões, ou deformidades, por processos manuais denominados operações ou intervenções cirúrgicas. Verifica-se atualmente o uso, cada vez mais freqüente, de cirurgia como sinônimo de operação ou intervenção cirúrgica. Dizer que a cirurgia tem por fim a prática de cirurgias, em lugar de operações, seria o mesmo que dizer que a obstetrícia tem por fim a prática de obstetrícias (em lugar de partos). Chamase a isso de tautologia. A prevalecer o uso de cirurgia como sinônimo de operação, é de se prever o aparecimento de um novo verbo - cirurgiar. Será, então, mais elegante dizer que o doente foi cirurgiado do que operado. A boa linguagem, tradicional, vernácula, correta, como ensina Becker em seu livro Nomenclatura biomédica no idioma português do Brasil manda dizer operação, reservando-se cirurgia para nomear o ramo da medicina que trata os enfermos por meio de operações.

Por sua vez, patologia vem do grego páthos, doença, e lógos, estudo, tratado. Etimologicamente, portanto, significa estudo as doenças. Define-se patologia como o ramo da medicina que descreve as alterações anatômicas e funcionais causadas pelas doenças no organismo. Quando nos referimos à patologia cirúrgica, obstétrica, pulmonar, ocular etc, estamos nos referindo ao estudo das alterações encontradas nas doenças cirúrgicas, obstétricas, pulmonares, oculares etc. Também se emprega em relação a cada doença em particular. Ex.: patologia da hipertensão arterial, patologia da febre tifóide, patologia da doença de Chagas etc. Não deve, entretanto, ser usado como sinônimo de doença, como ocorre freqüentemente. Ex.: “A patologia deste doente parece ser uma virose”; “o diabetes é uma patologia complexa”; “as patologias mais comuns na infância são as gastroenterites e as amigdalites” etc. Em nenhum dicionário, especializado ou não em termos médicos, encontra-se averbado o termo patologia como sinônimo de doença, enfermidade ou afecção. Dizer que o paciente tem uma patologia, seria o mesmo que dizer que o paciente tem uma cardiologia em lugar de uma cardiopatia (Becker). Como a evolução semântica das palavras é imprevisível, independentemente de sua correção, bem pode ser que tenhamos no futuro, a contragosto, de acrescentar mais um significado às palavras cirurgia e patologia.

\section{Referência}

1. Becker I. Nomenclatura biomédica no idioma português do Brasil. São Paulo: Livraria Nobel; 1968. 